INOBIS: Jurnal Inovasi Bisnis dan Manajemen Indonesia

Volume 1, Nomor 4, September 2018

Bambang Supeno

\title{
Analisis Pengaruh Modal Manusia, Modal Pelanggan, Modal Struktural terhadap Kinerja Usaha Ekonomi Kelurahan Simpan Pinjam di Pekanbaru
}

\author{
Bambang Supeno \\ f2bams@gmail.com
}

\section{Universitas Lancang Kuning Pekanbaru}

\begin{abstract}
Abstrak
Lembaga Keuangan Mikro (LKM) telah lama berperan dalam mengembangkan ekonomi rakyat dan memberdayakan masyarakat miskin, sementara LKM adalah salah satu pendekatan untuk mengatasi kemiskinan, karena dapat menjadi institusi yang menyediakan berbagai layanan keuangan, untuk kegiatan produktif dan konsumtif bagi keluarga miskin. Usaha Ekonomi Desa Simpan Pinjam (UED SP) sebagai salah satu LKM di Pekanbaru Provinsi Riau belum dapat menjawab kebutuhan masyarakat secara keseluruhan untuk bantuan modal usaha seperti yang diharapkan. Tujuan penelitian ini untuk menguji dan menganalisis pengaruh modal manusia, modal pelanggan, modal struktural terhadap kinerja UED SP di Pekanbaru Provinsi Riau. Analisis regresi linier digunakan untuk menguji model hipotesis secara statistik, serta untuk menentukan sejauh mana usulan penggunaan Model tersebut konsisten dengan data sampel. Hasil penelitian menunjukkan variabel modal manusia, modal pelanggan dan modal struktural baik secara parsial maupun simultan berpengaruh positif terhadap kinerja UED SP di Pekanbaru Provinsi Riau. Secara praktis, penelitian ini adalah diharapkan dapat memberikan dua manfaat: pertama: untuk memberikan pemahaman dan kesadaran kepada pengurus LKM UED SP bahwa mereka memiliki budaya organisasi yang dapat mempengaruhi kemampuan manajemen, strategi bisnis dan kinerja LKM UED SP. Kedua: memberikan kontribusi pemikiran kepada Pemerintah Daerah di Provinsi Riau dalam menentukan kebijakan pengembangan LKM UED SP.
\end{abstract}

Kata Kunci : Modal Manusia, Modal Pelanggan, Modal Strukturan, Kinerja Bisnis

\section{Pendahuluan}

Dalam mewujudkan kesejahteraan masyarakat, Pemerintahan Provinsi Riau, bekerjasama dengan Pemerintahan Kabupaten dan Kota se Provinsi Riau untuk melakukan kegiatan ekonomi secara nyata melalui Lembaga Keuangan Mikro Ekonomi Desa Simpan Pinjam (LMK UED-SP/LKM UEK-SP), yang berfokus pada kegiatan ekonomi desa atau kelurahan, guna membantu usaha mikro dalam menciptakan lapangan kerja dengan mempermudah persyaratan peminjaman modal.

Untuk itu dalam Angaran Pendapatan dan Belanja Negara (APBN) 2014 dilakukan penajaman program / kegiatan di seluruh sektor terkait melalui langkah kebijakan : (1) penciptaan kesempatan yang berkaitan dengan sasaran pemulihan ekonomi makro, perwujudan kepemerintahan yang baik, dan peningkatan pelayanan umum; (2) pemberdayaan masyarakat yang berkaitan dengan sasaran penyediaan akses masyarakat miskin ke sumberdaya ekonomi dan keterlibatan masyarakat dalam pengambilan keputusan; (3) peningkatan kemampuan yang berkaitan dengan sasaran peningkatan pelayanan pendidikan, kesehatan, pangan, perumahan agar masyarakat makin produktif; dan (4) perlindungan sosial yang berkaitan dengan sasaran pemberian jaminan kehidupan bagi masyarakat yang 
INOBIS: Jurnal Inovasi Bisnis dan Manajemen Indonesia

Volume 1, Nomor 4, September 2018

\section{Bambang Supeno}

mengalami kecacatan, fakir miskin, keterisolasian, konflik sosial, kehilangan pekerjaan sehingga berpotensi menjadi miskin.

Dwipayana (2007) mengungkapkan bahwa ada sejumlah masalah yang menghambat pembangunan di desa / kelurahan terutama di bidang ekonomi. Masalah tersebut bersumber dari (1) basis ekonomi masyarakat dan adanya jerat kemiskinan, (2) kuatnya intervensi negara yang tidak sejalan dengan prinsip good governance, (3) lemahnya organisasi ekonomi dan modal sosial serta, (4) jaringan pasar yang tidak mendukung penguatan ekonomi desa.

Salah satu upaya yang dapat ditempuh untuk mengatasi keadaan tersebut adalah melalui percepatan pemberdayaan dan pengembangan usaha mikro, karena sebagian pelaku usaha di Indonesia tergolong usaha mikro, kecil dan menegah (UMKM). Percepatan pemberdayaan dan pengembangan usaha mikro dapat dilakukan melalui Koperasi Simpan Pinjam (KSP) dan Koperasi Unit Desa (KUD) serta pegadaian. LKM informal terdiri dari berbagai kelompok dan Lembaga Swadaya Masyarakat, Lembaga Ekonomi Produktif Masyarakat Mandiri (LEPMM) dan Usaha Ekonomi Kelurahan Simpan Pinjam (UEK-SP).

Usaha Ekonomi Kelurahan Simpan Pinjam (UEK-SP) Sebagai suatu lembaga yang berperan sebagai perantara keuangan (financial intermediary) antara pihak-pihak yang memiliki dana (surplus unit) dengan pihak-pihak yang memerlukan dana, Usaha Ekonomi Kelurahan Simpan Pinjam (UEK-SP) memerlukan suatu kepercayaan dari masyarakat. Adanya kepercayaan masyarakat sebagai falsafah yang mendasari usaha bank menyebabkan modal manusia atau yang dikenal modal intelektual (intellectual capital) menjadi sangat kental pada bisnis perbankan maupun lembaga keuangan non bank. Hasil penelitian Brennan (2001) menunjukkan bahwa tingkat modal intelektual (intellectual capital) berpengaruh pada kinerja perusahaan yang meliputi produktivitas karyawan, peningkatan skill karyawan, dan peningkatan laba.

Modal intelektual adalah komponen penting di dalam organisasi. Pengembangan modal intelektual bagi organisasi pada hakekatnya adalah investasi yang bertujuan untuk memperbaiki kapasitas produktif dari manusia. Manusia dengan segala kemampuannya bila dikerahkan seluruhnya akan menghasilkan kinerja yang luar biasa. Peran baru sumber daya manusia dalam memberikan nilai tambah bagi organisasi agar lebih efektif dan kompetitif adalah melalui penurunan biaya, berorientasi pada pelanggan, meningkatnya produktifitas, serta komitmen pekerja. Oleh karena itu Usaha Ekonomi Kelurahan Simpan Pinjam (UEKSP) memiliki peran untuk menyiapkan sumber daya manusia yang kompeten dan handal sehingga mampu bersaing menghadapi perubahan dan perkembangan industri. Oleh karena itu Usaha Ekonomi Kelurahan Simpan Pinjam (UEK-SP) memiliki peran untuk menyiapkan sumber daya manusia yang kompeten dan handal sehingga mampu bersaing menghadapi perubahan dan perkembangan industri.

Untuk mengatasi permasalahan-permasalahan tersebut diperlukan pemberdayaan yang mampu meningkatkan kapasitas usaha mikro secara profesional, sistematik, dan berkelanjutan. Pemberdayaan dan pengembangan usaha mikro dapat dilakukan melalui berbagai program yang meliputi aspek-aspek penciptaan iklim usaha yang kondusif, dukungan pengembangan kemampuan usaha, dukungan pengembangan pasar, dukungan kemampuan usaha, strategi bisnis, kemampuanan manajemen, budaya organisasi, dan dukungan penyediaan pembiayaan.

Dalam rangka meningkatkan kemampuan berusaha bagi masyarakat desa, Pemerintah Provinsi Riau pada tahun 2005 menerbitkan Keputusan Gubernur Riau Nomor Kpts.132/III/2005 tanggal 31 Maret 2005 tentang Pedoman Umum dan Petunjuk Teknis Penyelenggaraan Program Pemberdayaan Desa (PPD). PPD adalah program yang bertujuan untuk mempercepat penanggulangan kemiskinan berdasarkan pengembangan ekonomi masyarakat melalui pemberian Dana Usaha Desa (DUD), memperkuat kelembagaan 
INOBIS: Jurnal Inovasi Bisnis dan Manajemen Indonesia

Volume 1, Nomor 4, September 2018

Bambang Supeno

desa/kelurahan, dan meningkatkan peran aktif instansi sektoral untuk memenuhi kebutuhan sarana/prasarana bagi masyarakat desa/kelurahan, serta mendorong pelembagaan sistem pembangunan partisipatif.

Penelitian yang dilakukan oleh Bambang Supeno dan Mujiono (2015) hasil penelitianya menunjukan bahwa secara parsial modal manusia dan modal pelanggan berpengaruh positif terhadap kinerja bisnis lembaga keuangan mikro usaha ekonomi desa simpan pinjam di Propinsi Riau. Secara simultan modal manusia dan modal pelanggan berpengaruh positif terhadap kinerja bisnis lembaga keuangan mikro usaha ekonomi desa simpan pinjam di Propinsi Riau.

Sementara hasil penelitian yang dilakukan oleh Ikbal wahid dan Muhammad Ridwan (2015) secara kulaitatif menunjukan bahwa pelaksaan TUPOKSI oleh pengelola UEK-SP belum terlaksana dengan baik, sehingga masyarakat yang mendapatkan manfaat dari program UEK-SP tidak tepat sasaran, yang berdampak pada tingginya kredit bermasalah dan perguliran dana pinjaman tidak dapat dilakukan setiap bulan yang berdampak pada antrian calon pemanfaan yang semakin menumpuk, hal ini dikarenakan kekurangan modal.

Berkenaan dengan hal tersebut, keberadaan skim pemberian modal yang diluncurkan oleh pemerintah Provinsi Riau dan Pemerintah Kota Pekanbaru melalui pendekatan UEK-SP tersebut memiliki peran strategis sebagai intermediasi dalam aktivitas perekonomian masyarakat dan UMKM.

Dengan kedudukannya yang penting dalam mendorong pengembangan usaha mikro melalui pemberdayaan masyarakat perdesaan, maka penelitian mengenai Analisis Pengaruh Modal Manusia, Modal Pelanggan, Modal Struktural terhadap Kinerja Usaha Ekonomi Kelurahan Simpan Pinjam di Pekanbaru menjadi sangat menarik dan penting. Penelitian ini dilakukan dengan mengambil lokasi penelitian di Kota Pekanbaru Provinsi Riau.

\section{Tinjauan Pustaka}

\section{Lembaga Keuangan Mikro}

Keuangan mikro (microfinance) merupakan alat yang penting dan strategis dalam mewujudkan pembangunan dalam tiga hal sekaligus, yaitu: menciptakan lapangan kerja, meningkatkan pendapatan masyarakat, dan mengentaskan kemiskinan. Akses terhadap jasa keuangan yang berkelanjutan merupakan prasyarat bagi masyarakat miskin dan pengusaha mikro untuk meningkatkan kemampuan dan kapasitas ekonominya.

Salah satu pendekatan yang dipergunakan dalam aplikasi konsep keuangan mikro adalah diarahkan pada upaya pengentasan kemiskinan melalui instrumen kredit yang biasanya disertai dengan layanan tambahan, seperti pelatihan baca tulis, menghitung, penyuluhan kesehatan dan gizi, kegiatan keagamaan dan lain sebagainya. Melalui pendekatan ini, pemerintah dan atau pihak donor membiayai kredit untuk orang miskin, dengan bunga di bawah suku bunga pasar. Sasarannya adalah orang miskin, untuk membantu keluar dari jerat kemiskinan serta memberdayakan mereka.

Menurut definisi yang dipakai dalam Microcredit Summit (1997) dalam Waloejo (2005), kredit mikro adalah program pemberian kredit berjumlah kecil ke warga paling miskin untuk membiayai proyek yang dia kerjakan sendiri agar menghasilkan pendapatan, yang memungkinkan mereka peduli terhadap diri sendiri dan keluarganya, "programmes extend small loans to very poor for self-employment projects that generate income, allowing them to care for themselves and their families" (Kompas, 15 Maret 2005). Sedangkan Bank Indonesia mendefinisikan kredit mikro merupakan kredit yang diberikan kepada para pelaku usaha 
INOBIS: Jurnal Inovasi Bisnis dan Manajemen Indonesia

Volume 1, Nomor 4, September 2018

\section{Bambang Supeno}

produktif baik perorangan maupun kelompok yang mempunyai hasil penjualan paling banyak seratus juta rupiah per tahun.

Menurut Rancangan Undang-Undang Lembaga Keuangan Mikro (RUU LKM), Keuangan Mikro didefinisikan sebagai layanan jasa keuangan berupa penghimpunan dana dan pemberian pinjaman dalam jumlah kecil, penyediaan jasa-jasa keuangan terkait yang ditujukan untuk kelompok masyarakat berpenghasilan rendah. Sedangkan pengertian umum LKM adalah lembaga keuangan penyedia jasa keuangan mikro (Salam, 2008;9).

\section{Usahan Ekonomi Desa/Kelurahan Simpan Pinjam}

Usaha Ekonomi Desa Simpan Pinjam (UED-SP) adalah kegiatan usaha ekonomi desa dalam bidang simpan pinjam yang diusahakan oleh pemerintah desa dan dibentuk berdasarkan hasil musyawarah desa untuk menentukan calon pengurus/pengelola UED-SP yang kemudian dibahas dalam rapat Badan Perwakilan Desa (BPD) agar mendapatkan pengesahan melalui Keputusan Desa (Dirjen PMD,1995).

Tujuan dibentuknya UED-SP adalah (Dirjen PMD, 1995):

1. Menciptakan iklim permodalan yang kondusif dan mendorong pembangunan ekonomi masyarakat desa.

2. Memberikan pinjaman bagi masyarakat yang membutuhkan modal untuk usaha baru dan pengembangan usaha.

3. Membantu pemerintah desa dalam peningkatan sumber Pendapatan Asli Desa (PAD).

4. Mengurangi dan mengatasi praktek negatif sistem ijon, pelepas uang, gadai gelap dan kegiatan lain yang sejenis.

5. Menciptakan pemerataan kesempatan berusaha bagi usaha kecil, tradisional dan usaha informal.

6. Meningkatkan pendapatan dan tabungan masyarakat desa.

7. Membantu masyarakat dalam penyediaan modal yang murah, cepat dan mudah dalam rangka menumbuhkembangkan usaha ekonomi desa.

8. Memperkecil ketergantungan akan dana bantuan pemerintah dalam pengembangan usaha ekonomi desa.

9. Menciptakan jiwa kewirausahaan bagi masyarakat desa.

Sasaran kegiatan UED-SP adalah masyarakat yang berada di desa/ kelurahan baik perorangan maupun kelompok yang akan memulai berusaha atau mengembangkan usahanya. Kegiatan UED-SP meliputi :

a. Memberikan pinjaman uang untuk kegiatan usaha masyarakat desa/ kelurahan yang dinilai produktif.

b. Menerima pinjaman uang dari masyarakat desa/ kelurahan sebagai anggota UED-SP.

c. Ikut serta memberikan bimbingan dan penyuluhan kepada anggota UED-SP dalam kaitan kegiatan usahanya.

d. Melaksanakan koordinasi dengan lembaga perbankan/ perkreditan lainnya dalam pelaksanaan simpan pinjam

Hak dan kewajiban anggota UED-SP diatur dalam anggaran dasar, antara lain (a) setiap anggota masyarakat yang berdomisili di desa berhak menjadi anggota UED-SP apabila memenuhi persyaratan sebagai anggota; (b) persyaratan menjadi anggota UED-SP adalah 
INOBIS: Jurnal Inovasi Bisnis dan Manajemen Indonesia

Volume 1, Nomor 4, September 2018

\section{Bambang Supeno}

masyarakt desa yang telah membayar simpanan pokok pendirian; (c) simpanan pokok pendirian untuk setiap anggota ditetapkan minimal pada nominal tertentu yang ditetapkan,per anggota, dapat dibayar secara angsuran paling lama dua bulan sejak permohonan menjadi anggota; (d) simpanan pokok tidak boleh diambil pemiliknya selama yang bersangkutan menjadi anggota UED-SP ; (e) setiap peminjam pada UED-SP wajib menyetor simpanan wajib pinjam (simwapin). Besarnya simwapin ditetapkan minimal 10 persen dari pokok pinjaman; (f) simwapin dapat diambil oleh anggota setelah pinjaman lunas.

Pengelola UED-SP terdiri dari : Ketua, Kasir dan Tata Usaha yang diangkat dan diberhentikan berdasarkan musyawarah LMD/BPD yang dinyatakan dengan Surat Keputusan Desa serta mempunyai masa kerja jabatan maksimal lima tahun dan setelah itu dapat dipilih kembali. Besarnya honorarium pengelola ditetapkan 2,5 persen dari jumlah pokok pinjaman yang diterima. Dalam anggaran dasar dijelaskan bahwa fungsi pengawasan terhadap pengelolaan UED-SP dilakukan oleh komisaris yang beranggotakan : Ketua LKMD, Kepala Desa/Lurah dan salah satu anggota yang ditunjuk untuk mewakili anggotanya.

Sumber modal UED-SP diperoleh dari : (1) modal sendiri : simpanan pokok, simpanan wajib pinjam, modal cadangan, modal gabungan, hibah; (2) modal bantuan ; berasal dari pemerintah atau bantuan pihak luar yang tidak mengikat; (3) modal pinjaman dan lembaga perbankan atau lembaga-lembaga lain serta dari masyarakat/anggota. Selanjutnya Sisa Hasil Usaha (SHU) UED-SP adalah pendapatan yang diperoleh dari hasil transaksi dikurangi dengan pengeluaran dan penyusutan barang-barang inventaris dalam satu tahun buku. Pembagian SHU ditetapkan berdasarkan anggran dasar yaitu : 25 persen untuk modal cadangan; 10 persen untuk anggota; 40 persen untuk honorarium pengelola; 10 persen untuk kontribusi pemerintahan desa; 10 persen untuk tenaga asistensi dan 5 persen untuk pendidikan pengelola UED-SP. Administrasi keuangan UED-SP menggunakan tahun buku dari 1 Januari sampai 31 Desember, dan UED-SP dapat saja dibubarkan jika terjadi kebangkrutan atau kerugian berdasarkan keinginan masyarakat melalui musyawarah BPD.

\section{Perkembangan Usahan Ekonomi Desa/Kelurahan Simpan Pinjam di Provinsi Riau}

Berdasarkan data dari Kanwil Badan Pertanahan Nasional Provinsi Riau, Provinsi Riau memiliki luas area sebesar 8867267 Hektar. Keberadaannya membentang dari lereng Bukit Barisan sampai dengan Selat Malaka, terletak antara $01^{\circ} 05^{\prime} 00^{\prime}$ ' Lintang Selatan sampai $02^{\circ} 25^{\prime} 00^{\prime}$ ' Lintang Utara atau antara $100^{\circ} 00^{\prime} 00^{\prime}$ ' Bujur Timur- $105^{\circ} 05^{\prime} 00^{\prime}$ ' Bujur Timur.

Di daerah daratan terdapat 15 sungai, di antaranya ada 4 sungai yang mempunyai arti penting sebagai prasarana perhubungan seperti Sungai Siak $(300 \mathrm{~km})$ dengan kedalaman 8-12 m, Sungai Rokan $(400 \mathrm{~km})$ dengan kedalaman 6-8 m, Sungai Kampar (400 km) dengan kedalaman lebih kurang $6 \mathrm{~m}$ dan Sungai Indragiri $(500 \mathrm{~km})$ dengan kedalaman 6-8 m. Ke 4 sungai yang membelah dari pegunungan dataran tinggi Bukit Barisan bermuara di Selat Malaka dan Laut Cina Selatan itu dipengaruhi pasang surut laut.

Batas-batas daerah Riau adalah:

- Sebelah Utara:

Selat Malaka dan Provinsi Sumatera Utara

- Sebelah Selatan:

Provinsi Jambi dan Provinsi Sumatera Barat

- Sebelah Timur:

Provinsi Kepulauan Riau dan Selat Malaka 
INOBIS: Jurnal Inovasi Bisnis dan Manajemen Indonesia

Volume 1, Nomor 4, September 2018

Bambang Supeno

- Sebelah Barat:

Provinsi Sumatera Barat dan Provinsi Sumatera Utara

Dalam hal pengembangan UED SP dan BUMDES ini Provinsi Riau dapat penulis kategorikan cukup sukses dalam melahirkan dan mengembangkan LKM ini sebagai pilar ekonomi dan pilar sosial di seluruh desa/ kelurahan di Provinsi Riau. Saat ini saja Provinsi Riau memiliki 1.843 desa. Dari jumlah desa tersebut tercatat 989 desa telah memiliki Usaha Ekonomi Desa Simpan Pinjam (UED SP). Dengan demikian 854 desa (46,3 persen) masih tercatat belum menerima dana UED SP. Data Bapemas Bangdes terbaru menyebutkan bahwa melalui UED SP yang telah didirikan tersebut telah disalurkan Rp456 miliar di mana Rp210 miliar untuk 422 desa dananya bersumber dari dana provinsi dan Rp245 miliar untuk 567 desa berasal dari dana kabupaten/ kota.

Alokasi dana yang cukup besar ini dengan putaran sampai dengan Rp1,3 triliun ini ke depan tentu saja diprediksi akan semakin memerlukan profesionalisme sumber daya insaninya terkait dengan keperluan LKM sebagai lembaga bisnis dan ekonomi yang harus mampu menampilkan kinerja dan akuntabilitas pengelolaan yang baik untuk menghindari terjadinya moral hazard dari pengelola maupun penggunanya.

Adapun jumlah pemanfaat dana usaha desa UED/K SP sampai tahun 2013 berdasarkan laporan Team Leader PPD adalah 195.000 orang lebih, dengan penerima manfaat terbanyak jenis usaha perkebunan (55\%), perdagangan (32\%), Jasa (6\%), Pertanian, perikanan dan peternakan masing-masing $2 \%$, dan industry $1 \%$. Tingkat pengembalian pinjaman rata-rata untuk desa yang masih dalam pembinaan Pemerintah Propinsi sebesar 95,7 $\%$. Sedangkan desa yang telah diserahkan kepada Pemerintah Kabupaten/Kota, data terkini dan akurat belum diperoleh baik dari fasilitator program maupun dari BPMPD Kabupaten/Kota se Provinsi Riau. Sedangkan pemanfaat dari masyarakat miskin 4.847 orang atau $2,48 \%$ dari target program minimal $10 \%$ per tahun per desa lokasi UED/K-SP.

\section{Kinerja Usaha Ekonomi Kelurahan Simpan Pinjam}

Definisi dari kinerja dapat bervariasi dari satu ukuran ke ukuran lain. Mitchell (2002) memandang bahwa kinerja perusahaan dapat diukur dalam empat dimensi :

1. Relevansi, merupakan tingkat dimana para stakeholder dari perusahaan memandang perusahaan tersebut telah sesuai dengan keinginan mereka. Klien menilai relevansi produk dengan membeli mereka, karyawan dengan bekerja keras, pemegang saham dengan membeli dan menjual saham dan lain lain.

2. Efektivitas, merupakan tingkat sejauh mana perusahaan sukses dalam meraih tujuan yang telah ditetapkan sebelumnya.

3. Efisiensi, merupakan sebaik mana perusahaan menggunakan sumberdaya yang dimilikinya dalam mencapai tujuannya.

4. Kelayakan keuangan, merupakan seberapa layak perusahaan dipandang dari segi keuangan, yang mencerminkan profitabilitas perusahaan baik dalam jangka pendek maupun jangka panjang

Dilakukannya pengukuran atas penilaian prestasi atau kinerja suatu perusahaan (business performance) karena dapat dipakai sebagai dasar dalam pengambilan keputusan baik pihak internal maupun eksternal. Di dalam sistem kontrol formal, ukuran kinerja meliputi ukuran financial dan non financial (Fisher, 1998) dalam (Astuti dan Sabeni, 2005). Kinerja 
INOBIS: Jurnal Inovasi Bisnis dan Manajemen Indonesia

Volume 1, Nomor 4, September 2018

\section{Bambang Supeno}

keuangan perusahaan (ukuran financial) lebih berorientasi jangka pendek, yaitu untuk mencari keuntungan atau profit. Ukuran dari jangka pendek adalah sekitar satu tahun siklus hidup perusahaan. Sedangkan kinerja non keuangan perusahaan (ukuran non financial) lebih bersifat jangka panjang, misalnya untuk menciptakan value (nilai) serta menjaga agar perusahaan tetap dapat bertahan hidup, tumbuh, dan berkembang. Orientasi jangka panjang umumnya adalah lebih dari satu tahun siklus hidup perusahaan

Menurut Bontis dan Fitz-Enz (2002) terdapat empat elemen modal intelektual yaitu modal manusia, pelanggan modal, modal inovasi, dan modal proses, setiap elemen secara langsung dapat mempengaruhi kinerja. Artinya, modal manusia yang merupakan paling mendasar dalam unsur modal intelektual, dapat pempengaruhi tiga unsur lainya, pada gilirannya mempengaruhi kinerja.

\section{Modal Intelektual}

Tidaklah mudah untuk dapat menyajikan definisi yang tepat tentamg IC. Ada banyak definisi berbeda mengenai modal intelektual. Modal intelektual adalah informasi dan pengetahuan yang diaplikasikan dalam pekerjaan untuk menciptakan nilai (Williams, 2001 dalam Purnomosidhi, 2006). Modal intelektual adalah materi intelektual yang telah diformalisasikan, ditangkap, dan diungkit untuk menciptakan kekayaan, dengan menghasilkan suatu aset yang bernilai tinggi (Ulum, 2009:24).

Intellectual Capital adalah informasi dan pengetahuan yang diaplikasikan dalam pekerjaan untuk menciptakan nilai. Intellectual Capital dapat dipandang sebagai pengetahuan, dalam pembentukan, kekayaan intelektual dan pengalaman yang dapat digunakan untuk menciptakan kekayaan. Ada banyak definisi berbeda mengenai Intellectual Capital

The Society of management Accountants of Canada (SMAC) mendefinisikan intellectual assets sebagai berikut: In balance sheet are those knowledge-based items, which the company owns which will produced a future stream of benefits for the company (IFAC, 1998 dalam Sawarjuwono, 2003).

Intellectual Capital pada umumnya diklasifikasikan menjadi tiga bagian yaitu: Human Capital (HC), Structural Capital (SC), dan Customer Capital (CC). Dimana Human Capital merepresentasikan individual knowledge stock suatu organisasi yang direpresentasikan oleh karyawannya. Human Capital merupakan kombinasi dari genetic inheritance; education; experience, dan attitude tentang kehidupan dan bisnis. Structural capital meliputi seluruh nonhuman storehouses of knowledge dalam organisasi. Termasuk dalam hal ini adalah database, organisational charts, process manuals, strategies, routines dan segala hal yang membuat nilai perusahaan lebih besar daripada nilai materialnya, sedangkan tema utama dari customer capital adalah pengetahuan yang melekat dalam marketing channels dan customer relationship dimana suatu organisasi mengembangkannya melalui jalannya bisnis

Modal intelektual mencakup semua pengetahuan karyawan, organisasi, dan kemampuan mereka untuk menciptakan nilai tambah dan menyebabkan keunggulan kompetitif berkelanjutan. Dari definisi tersebut dapat disimpulkan bahwa intellectual capital merupakan sumber daya yang dimiliki oleh suatu perusahaan yang nantinya akan memberikan keuntungan dimasa mendatang bagi perusahaan yang dapat dilihat dari kinerja perusahaan tersebut.

Bontis (1998) menyatakan bahwa modal intelektual merupakan 'saham' dari pengetahuan yang ada dalam suatu organisasi. Modal intelektual berkaitan dengan semua organisasi pengetahuan yang implisit dan eksplisit, serta individu dan kolektif. Modal intelektual bukan merupakan sesuatu yang bersifat mudah dan sederhana, akan tetapi terkait 
INOBIS: Jurnal Inovasi Bisnis dan Manajemen Indonesia

Volume 1, Nomor 4, September 2018

\section{Bambang Supeno}

dengan kecerdasan manusia yang memiliki kebebasan dalam berpikir untuk menciptakan sesuatu yang bersifat inovatif dan kreatif demi perkembangan dan kemajuan organisasi.

\section{Modal Manusia}

Human Capital merupakan lifeblood dalam modal intelektual. Disinilah sumber innovation dan improvement, tetapi merupakan komponen yang sulit untuk diukur. Human capital juga merupakan tempat bersumbernya pengetahuan yang sangat berguna, keterampilan, dan kompetensi dalam suatu organisasi atau perusahaan. Human capital mencerminkan kemampuan kolektif perusahaan untuk menghasilkan solusi terbaik berdasarkan pengetahuan yang dimiliki oleh orang-orang yang ada dalam perusahaan tersebut. Human capital akan meningkat jika perusahaan mampu menggunakan pengetahuan yang dimiliki oleh karyawannya. Brinker (2000) memberikan beberapa karakteristik dasar yang dapat diukur dari modal ini, yaitu training programs, credential, experience, competence, recruitment, mentoring, learning programs, individual potential and personality.

Menurut Malhotra dan Bontis (dalam Rahmawati dan Wulani 2004), Human Capital merupakan kombinasi dari pengetahuan,keterampilan, inovasi, dan kemampuan seseorang untuk menjalankan tugasnya sehingga dapat menciptakan suatu nilai untuk mencapai tujuan. Pembentukan nilai tambah dikontribusikan oleh human capital dalam menjalankan tugas dan pekerjaannya akan memberikan suistanable revenue di masa yang akan datang bagi suatu organisasi.

Stockely (2003) mendefinisikan bahwa modal manusia merupakan asset yang penting dan beresensi, memiliki sumbangan terhadap pengembangan dan pertumbuhan, sama halnya modal fisik seperti: mesin dan modal kerja lainnya. Sikap, ketrampilan dan kemampuan manusia mempunyai kontribusi terhadap produktivitas dan kinerja organisasi. Pengeluaran untuk pelatihan, pengembangan, pendidikan dan dukungan merupakan investasi bukan merupakan biaya.

\section{Modal Pelanggan}

Elemen ini merupakan komponen modal intelektual yang memberikan nilai secara nyata. Relational Capital merupakan hubungan yang harmonis/association network yang dimiliki oleh perusahaan dengan para mitranya, baik yang berasal dari para pemasok yang andal dan berkualitas, berasal dari pelanggan yang loyal dan merasa puas akan pelayanan perusahaan yang bersangkutan, berasal dari hubungan perusahaan dengan pemerintah maupun dengan masyarakat sekitar. Relational Capital dapat muncul dari berbagai bagian diluar lingkungan perusahaan yang dapat menambah nilai bagi perusahaan tersebut.

Modal Relasional merupakan hubungan yang harmonis dalam association network yang dimiliki oleh perusahaan dengan para mitranya, dari pemasok, pelanggan, masyarakat sekitar maupun pemerintah. Customer capital dapat muncul dari berbagai bagian diluar lingkungan perusahaan yang dapat menambah nilai bagi perusahaan tersebut (Sawarjuwono \& Kadir, 2005).

Modal pelanggan merupakan komponen modal intelektual yang memberikan nilai secara nyata (Bontis: 1998). Elemen ini merupakan hubungan yang harmonis yang dimiliki oleh perusahaan dengan para mitranya, baik yang berasal dari para pemasok yang andal dan berkualitas, berasal dari pelanggan yang loyal dan merasa puas akan pelayanan perusahaan yang bersangkutan, berasal dari hubungan perusahaan dengan pemerintah maupun dengan masyarakat sekitar. 
INOBIS: Jurnal Inovasi Bisnis dan Manajemen Indonesia

Volume 1, Nomor 4, September 2018

Bambang Supeno

\section{Modal Struktural}

Structural Capital merupakan kemampuan organisasi atau perusahaan dalam memenuhi proses rutinitas perusahaan dan strukturnya yang mendukung usaha karyawan untuk menghasilkan kinerja intelektual yang optimal serta kinerja bisnis secara keseluruhan, misalnya: sistem operasional perusahaan, proses manufacturing, budaya organisasi, filosofi manajemen dan semua bentuk intellectual property yang dimiliki perusahaan. Seorang individu dapat memiliki tingkat intelektualitas yang tinggi, tetapi jika organisasi memiliki sistem dan prosedur yang buruk maka intellectual capital tidak dapat mencapai kinerja secara optimal dan potensi yang ada tidak dapat dimanfaatkan secara maksimal.

Modal struktural ini berkaitan dengan mekanisme dan struktur organisasi yang dapat membantu mendukung karyawan dalam meningkatkan kinerja intelektual secara optimal dan kinerja bisnis secara keseluruhan. Seorang individu dapat memiliki tingkat kecerdasan yang tinggi, tetapi jika organisasi memiliki struktur yang buruk dan prosedur yang tidak teratur, akan mengakibatkan potensi modal intelektual yang dimiliki organisasi tidak dapat dimanfaatkan secara maksimal. Sebuah organisasi dengan modal struktur yang kuat akan memiliki budaya yang mendukung yang memungkinkan individu untuk mencoba hal-hal yang gagal, kemudian belajar untuk memperbaikinya, dan mencobanya lagi. Jika budaya organisasi terlalu menghukum kegagalan, maka organisasi akan mendapatkan keberhasilan yang minimal (Bontis: 1998).

Wang dan Chan (2005) mendeskripsikan bahwa structural capital memiliki hubungan dengan sistem dan struktur perusahaan yang dapat membantu karyawan untuk mencapai kinerja intelektual maksimal mereka, sehingga kinerja perusahaan secara keseluruhan dapat meningkat. Secara lebih detail, structural capital dapat diklasifikasikan menjadi budaya perusahaan, struktur organisasi, pembelajaran organisasi, proses operasional perusahaan dan sistem informasi.

\section{Metode Penelitan}

Jenis penelitian ini adalah penelitian deskriptif kuantitatif yaitu yang membahas pengaruh variabel independen (modal manusia, modal pelanggan, modal struktural) dengan variabel dependen (kinerja usaha ekonomi kelurahan simpan pinjam), dan jenis penelitian ini adalah deskriptif explanatory yaitu menjelaskan variabel independen (modal manusia, modal pelanggan, modal struktural) dan variabel dependen (kinerja usaha ekonomi kelurahan simpan pinjam) yang diteliti serta hubungan variabel independen dengan variabel dependen. Populasi dalam penelitian ini adalah Lembaga Ekonomi Mikro UEK SP yang berada di Kodya Pekanbaru periode laporan keuangan tahun 2013-2015 berjumlah 57 UEK SP. Pengambilan sampel penelitian ini menggunakan Sensus Sampling. Metode ini dipilih karena sampel akan diambil berdasarkan kriteria yang ditetapkan oleh peneliti, dimana target responden adalah LKM UEK SP. Sampel pada penelitian ini berjumlah 57 UEK SP. Analisis data yang digunakan dalam penelitian ini adalah Regresi Linier Ganda dengan dengan persamaan regresi

$$
Y=a+b_{1} x_{1} X_{1}+b_{2} x_{2} X_{2}+b_{3} x_{3} X_{3}+e
$$

$$
\begin{array}{ll}
\underset{\operatorname{Dimana}:}{\mathrm{Y}} & =\text { Kinerja Usaha Ekonomi Kelurahan Simpan Pinjam } \\
\mathrm{a} & =\text { Konstanta } \\
\mathrm{b}_{1} ; \mathrm{b}_{2} ; \mathrm{b}_{3}= & \text { Slope kemiringan garis regresi atau koefisien masing-masing variabel } \\
& \text { independen } \\
\mathrm{X}_{1} & =\text { Modal Manusia }
\end{array}
$$


INOBIS: Jurnal Inovasi Bisnis dan Manajemen Indonesia

Volume 1, Nomor 4, September 2018

Bambang Supeno

$$
\begin{array}{ll}
\mathrm{X}_{2} & =\text { Modal Pelanggan } \\
\mathrm{X}_{3} & =\text { Modal Struktural } \\
\mathrm{e} & =\text { Error }
\end{array}
$$

Dalam pengujian Uji regresi liner ganda didahului dengan uji validitas dan reliabilitas data, uji normalitas, uji autokorelasi, uji multikolinieritas dan uji heteroskedastisitas. Pengujian hipotesis menggunakan uji t, uji F dan Determinasi.

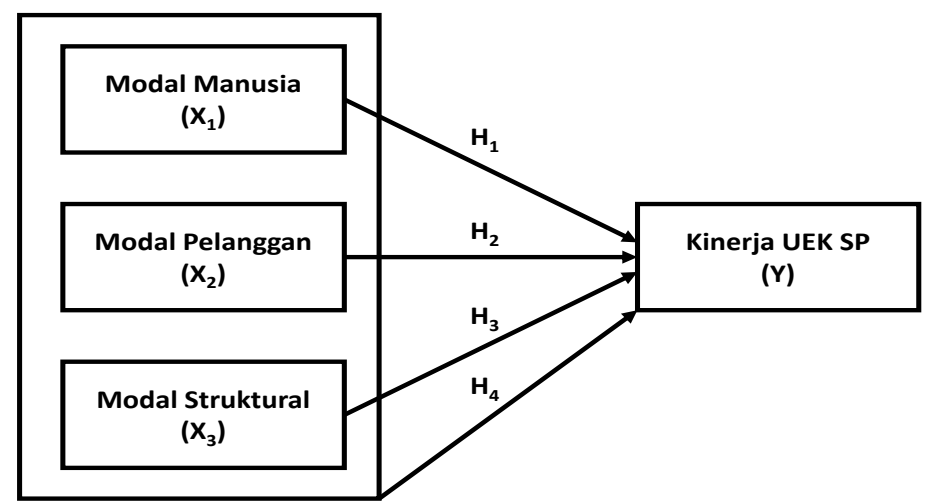

Gambar 1. Model Kerangka Penelitian

\section{Pembahasan}

\section{Uji Validitas dan Reliabilitas}

Hasil uji statistik variabel modal pelanggan $\left(\mathrm{X}_{2}\right)$ tampak pada tabel 1 bahwa nilai KMO sebesar 0,727 yang menandakan bahwa instrimen variabel modal pelanggan yaitu pentingnya kualitas $\left(\mathrm{X}_{2.1}\right)$, penggalian kepuasan pelanggan $\left(\mathrm{X}_{2.2}\right)$ dan tindak lanjut kebutuhan pelanggan $\left(\mathrm{X}_{2.3}\right)$ semuanya valid, yang dibuktikan dari nilai KMO lebih besar dari 0,05, dan

\begin{tabular}{|c|c|c|c|c|c|}
\hline Indikator & $\mathbf{N}$ & KMO & $\begin{array}{c}\text { Korelasi Anti } \\
\text { Image }\end{array}$ & $\begin{array}{l}\text { Menjelaskan } \\
\text { Konstruk (\%) }\end{array}$ & Keterangan \\
\hline $\mathbf{X 2 . 1}$ & 57 & \multirow{3}{*}{0,727} & \begin{tabular}{|l|l|}
0.764 \\
\end{tabular} & \multirow{3}{*}{31,09} & Valid \\
\hline X2.2 & 57 & & 0.754 & & Valid \\
\hline $\mathrm{X} 2.3$ & 57 & & 0.828 & & Valid \\
\hline
\end{tabular}
ketiga instrumen mampu menjelaskan konstruk sebesar 31,09\%.

Tabel 1. Uji Validitas Variabel Modal Pelanggan $\left(\mathbf{X}_{2}\right)$

(Sumber : Data olahan, 2017)

Dari tabel 2 di terlihat bahwa nilai KMO sebesar 0,678 yang menandakan bahwa instrimen variabel modal struktural yaitu implementasi ide baru $\left(\mathrm{X}_{3.1}\right)$, dukungan terhadap pengembangan ide $\left(\mathrm{X}_{3.2}\right)$, sistem yang memberikan kemudahan akses informasi $\left(\mathrm{X}_{3.3}\right)$. semuanya valid, yang dibuktikan dari nilai KMO lebih besar dari 0,05, dan ketiga instrumen

\begin{tabular}{|c|c|c|c|c|c|}
\hline Indikator & $\mathbf{N}$ & KMO & $\begin{array}{c}\text { Korelasi Anti } \\
\text { Image }\end{array}$ & $\begin{array}{l}\text { Menjelaskan } \\
\text { Konstruk (\%) }\end{array}$ & Keterangan \\
\hline X3.1 & 57 & \multirow{3}{*}{0,678} & 0.674 & \multirow{3}{*}{62,26} & Valid \\
\hline$\times 3.2$ & 57 & & 0.671 & & Valid \\
\hline X3.3 & 57 & & 0.678 & & Valid \\
\hline
\end{tabular}
mampu menjelaskan konstruk sebesar $62,26 \%$.

Tabel 2. Uji Validitas Variabel Modal Struktural $\left(\mathbf{X}_{3}\right)$

(Sumber : Data olahan, 2017) 
INOBIS: Jurnal Inovasi Bisnis dan Manajemen Indonesia

Volume 1, Nomor 4, September 2018

Bambang Supeno

Selanjutnya uji reliabilitas yang di ukur dengan alpha cronbach dengan batasan dikatakan reliabel jika nilai alpha cronbach lebih besar dari 0,60. Hasil pengukuran alpha cronbach bahwa instrumen variabel modal pelanggan $\left(\mathrm{X}_{2}\right)$ yaitu pentingnya kualitas $\left(\mathrm{X}_{2.1}\right)$, penggalian kepuasan pelanggan $\left(\mathrm{X}_{2.2}\right)$ dan tindak lanjut kebutuhan pelanggan $\left(\mathrm{X}_{2.3}\right)$ dapat di simpulkan reliabel yaitu alpha cronbach 0,676 > 0,60, dan nilai corrected item - total correction ketiga instrumen di atas 0,30 , yang tampak pada tabel 3 .

Tabel 3. Uji Reliabilitas Variabel Modal Pelanggan $\left(\mathbf{X}_{2}\right)$

\begin{tabular}{|c|c|c|c|c|}
\hline Indikator & $\mathbf{N}$ & $\begin{array}{c}\text { Alpha } \\
\text { Cronbach }\end{array}$ & $\begin{array}{c}\text { Corrected Item- } \\
\text { Total Correlation }\end{array}$ & Keterangan \\
\hline X2.1 & 57 & \multirow{3}{*}{0.767} & $\mathbf{0 , 5 4 3}$ & Reliabel \\
\cline { 1 - 2 } \cline { 4 - 5 } X2.2 & 57 & $\mathbf{0 , 4 2 1}$ & Reliabel \\
\hline X2.3 & 57 & & $\mathbf{0 , 5 5 6}$ & Reliabel \\
\cline { 5 - 5 } & & &
\end{tabular}

(Sumber : Data olahan, 2017)

Pada tabel 4 menunjukan hasil pengukuran alpha cronbach instrumen variabel modal Struktural $\left(\mathrm{X}_{3}\right)$ yaitu implementasi ide baru $\left(\mathrm{X}_{3.1}\right)$, dukungan terhadap pengembangan ide $\left(\mathrm{X}_{3.2}\right)$, sistem yang memberikan kemudahan akses informasi $\left(\mathrm{X}_{3.3}\right)$ dapat di simpulkan reliabel yaitu alpha cronbach $0,726>0,60$, dan nilai corrected item - total correction ketiga instrumen di atas 0,30 .

Tabel 4. Uji Reliabilitas Variabel Modal Struktural $\left(\mathbf{X}_{3}\right)$

\begin{tabular}{|c|c|c|c|c|}
\hline Indikator & $\mathbf{N}$ & \multirow{2}{*}{$\begin{array}{c}\text { Alpha } \\
\text { Cronbach }\end{array}$} & $\begin{array}{c}\text { Corrected Item- } \\
\text { Total Correlation }\end{array}$ & Keterangan \\
\hline X3.1 & 57 & \multirow{3}{*}{0.726} & $\mathbf{0 , 5 3 3}$ & Reliabel \\
\hline X3.2 & 57 & \multirow{2}{*}{$\mathbf{0}$} & $\mathbf{0 , 5 2 5}$ & Reliabel \\
\cline { 1 - 3 } \cline { 4 - 5 } & 57 & & $\mathbf{0 , 5 1 6}$ & Reliabel \\
\hline
\end{tabular}

(Sumber : Data olahan, 2017)

\section{Uji Asumsi Klasik}

Hasil pengujian normalitas diketahui hasil perhitungan skeweness dan kurtosis sebesar 0,4282 dan $-0,4897$, ini telah memenuhi syarat normaltas yaitu bila rasio skeweness dan kurtosis berada di antara -2 dan +2 berarti berdistribusi normal.

Hasil uji autokorelasi $\mathrm{Dw}_{\text {hitung }}$ sebesar 1,899, dengan sampel $(\mathrm{N})$ sebanyak 57 dan variabel independen 3, maka di ketahui $\mathrm{Du}_{\text {tabel }}$ sebesar 1,684. dimana $\mathrm{Du}<\mathrm{Dw}_{\text {hitung }}<4-\mathrm{Du}$, yaitu $1,684<1,899<4-1,684=1,684<1.899<2,315$, dengan demikian dapat disimpulkan tidak ada autokorelasi antar variabel penelitian.

Hasil uji multikolinieritas menunjukkan semua nilai VIF variabel bebas lebih kecil dari 10 dan nilai toleran lebih besar dari 0,10 . Masing-masing variabel bebas yaitu variabel modal manusia $\left(\mathrm{X}_{1}\right)$ nilai VIF 1,227 dengan nilai toleran 0,815 , variabel modal pelanggan $\left(\mathrm{X}_{2}\right)$ nilai VIF 1,227 dengan nilai toleran 0,815 , dan variable modal struktural $\left(\mathrm{X}_{3}\right)$ nilai VIF 1,229 dengan nilai toleran 0,815 maka dapat dinyatakan secara keseluruhan tidak ada multikolinieritas antar variabel penelitian.

Hasil uji hetroskedastisitas menunjukan bahwa keseluruhan nilai t-statistik variabel bebas tidak ada yang signifikan yaitu variabel modal manusia $\left(X_{1}\right) \operatorname{Sig}=0,246$, variabel modal 
INOBIS: Jurnal Inovasi Bisnis dan Manajemen Indonesia

Volume 1, Nomor 4, September 2018

\section{Bambang Supeno}

pelanggan $\left(\mathrm{X}_{2}\right)$ Sig=0,229 dan variable modal structural $\left(\mathrm{X}_{3}\right)$ Sig=0,324, sehingga dapat disimpulkan model regresi tidak mengalami masalah heteroskedastisitas.

\section{Uji Regresi}

Nilai signifikansi variabel modal manusia $\left(\mathrm{X}_{1}\right)$ terhadap variabel kinerja bisnis $(\mathrm{Y})$ sebesar 0,001 atau lebih kecil dari nilai alpha sebesar 0,05 dengan nilai koefisien regresi 0,543 , artinya terdapat pengaruh positif signifikan variabel modal manusia $\left(\mathrm{X}_{1}\right)$ secara parsial terhadap variabel kinerja bisnis (Y). Koefisien regresi sebesar 0,543 ini mengartikan modal manusia $\left(\mathrm{X}_{1}\right)$ meningkat sebesar 1 satuan, maka variable kinerja bisnis(Y) akan meningkat sebesar sebesar 0,543, dengan asumsi variabel modal pelanggan $\left(\mathrm{X}_{2}\right)$ dan modal structural $\left(\mathrm{X}_{3}\right)$ konstan.

Tabel 5. Hasil Regresi Linier Ganda

\begin{tabular}{|c|c|c|c|c|c|c|c|}
\hline Variabel & $\begin{array}{c}\text { Koefisien } \\
\text { Regresi }\end{array}$ & $\begin{array}{c}\text { Standart } \\
\text { Error }\end{array}$ & $\mathbf{t}_{\text {hitung }}$ & Probabilitas & Keseimpulan & Toleran & VIF \\
\hline Konstanta & 0,883 & 5,736 & 0,271 & 0.023 & - & - & - \\
\hline Modal Manusia (X1) & 0,543 & 0,078 & 10,824 & 0,001 & Signifikan & 0.815 & 1.227 \\
\hline Modal Pelanggan (X2) & 0,443 & 0,089 & 7,824 & 0,017 & Signifikan & 0.815 & 1.227 \\
\hline Modal Struktural (X3) & 0,703 & 0,109 & 8,244 & 0,000 & Signifikan & 0.815 & 1.229 \\
\hline Alpha & 0,05 & & $F_{\text {hitung }}$ & 76,585 & Sig : 0,000 & & \\
\hline $\mathbf{R}$ & 0,879 & & $\mathbf{F}_{\text {tabel }}$ & 2,77 & $t_{\text {tabel }}$ & 1,672 & \\
\hline R Square & 0,772 & & $D w_{\text {hitung }}$ & 1,899 & $D w_{\text {tabel }}$ & 1,684 & \\
\hline Adjusted R Square & 0,765 & & $\mathbf{N}$ & 57 & & & \\
\hline
\end{tabular}

(Sumber : Data olahan, 2017)

Nilai signifikansi variabel modal pelanggan $\left(\mathrm{X}_{2}\right)$ terhadap variabel kinerja bisnis $(\mathrm{Y})$ sebesar 0,017 atau lebih kecil dari nilai alpha sebesar 0,05 dengan nilai koefisien regresi 0,443 , artinya terdapat pegaruh positif signifikan variabel modal pelanggan (X2) secara parsial terhadap variabel kinerja bisnis (Y). Nilai koefisien sebesar 0,443 ini mengartikan jika variabel modal pelanggan $\left(\mathrm{X}_{2}\right)$ meningkat sebesar 1 satuan maka variabel kinerja bisnis $(\mathrm{Y})$ meningkat sebesar 0,443 dengan asumsi variabel modal manusia $\left(\mathrm{X}_{1}\right)$, modal struktural $\left(\mathrm{X}_{3}\right)$ konstan.

Nilai signifikansi variabel modal struktural $\left(\mathrm{X}_{3}\right)$ terhadap variabel kinerja bisnis $(\mathrm{Y})$ sebesar 0,000 atau lebih kecil dari nilai alpha sebesar 0,05 dengan nilai Koefisien regresi 0,703 , artinya terdapat pegaruh positif signifikan variabel modal struktural $\left(\mathrm{X}_{3}\right)$ secara parsial terhadap variabel kinerja bisnis (Y). Nilai koefisien sebesar 0,703 ini mengartikan jika variabel modal struktural $\left(\mathrm{X}_{3}\right)$ meningkat sebesar 1 satuan maka variabel kinerja bisnis $(\mathrm{Y})$ meningkat sebesar 0,702 dengan asumsi variabel modal manusia $\left(\mathrm{X}_{1}\right)$ dan modal pelanggan (X2) konstan.

Dari hasil uji regresi linier di atas, kemudian dimasukan kedalam persamaan regresi :

$$
Y=0.883+0.543 X_{1}+0,443 X_{2}+0,703 X_{3}+0,228
$$

Nilai signifikansi variabel modal manusia $\left(\mathrm{X}_{1}\right)$, modal pelanggan $\left(\mathrm{X}_{2}\right)$ dan modal structural $\left(\mathrm{X}_{3}\right)$ terhadap variabel kinerja bisnis $(\mathrm{Y})$ sebesar 0,000 atau lebih kecil dari nilai alpha sebesar 0,05 dengan $F_{\text {hitung }}>F_{\text {tabel }}$ yaitu 75,585 $>2,77$, artinya terdapat pegaruh variabel modal manusia $\left(\mathrm{X}_{1}\right)$, modal pelanggan $\left(\mathrm{X}_{2}\right)$ dan modal struktural $\left(\mathrm{X}_{3}\right)$ secara simultan terhadap variabel kinerja bisnis (Y) secara positif. Nilai R Square sebesar 0,772 mengartikan 
INOBIS: Jurnal Inovasi Bisnis dan Manajemen Indonesia

Volume 1, Nomor 4, September 2018

Bambang Supeno

bahwa pengaruh variabel modal manusia $\left(\mathrm{X}_{1}\right)$, modal pelanggan $\left(\mathrm{X}_{2}\right)$ dan modal struktural $\left(\mathrm{X}_{3}\right)$ secara simultan terhadap variabel kinerja bisnis $(\mathrm{Y})$ sebesar 77,2\%.

\section{Pengaruh Modal Manusia $\left(\mathrm{X}_{1}\right)$ terhadap Kinerja Bisnis (Y)}

Variabel modal manusia mempunyai pengaruh positif dan signifikan terhadap kinerja bisnis. Temuan ini sesuai dengan prediksi hipotesis $\left(\mathrm{H}_{1}\right)$ yang memprediksi bahwa modal manusia secara positif dan signifikan berpengaruh terhadap kinerja bisnis lembaga keuangan mikro usaha ekonomi kelurahan simpan pinjam. Makna dari temuan ini menunjukkan bahwa secara empiris modal manusia berpengaruh dalam meningkatkan kinerja bisnis secara positif, yaitu bila modal manusia meningkat maka kinerja bisnis juga meningkat.

Hasil penelitian ini sesuai dengan hasil penelitian dari Bontis (1998) Partial Least Square (PLS). Dari hasil penelitian menunjukkan bahwa pengukuran yang subyektif dan terstruktur secara optimal akan menunjukkan valid, realibel, signifikan dan substantive berhubungan antara dimensi intellectual capital dengan business performance.

Modal manusia merupakan potensi organisasi berupa pengetahuan individu yang tersembunyi, yaitu keterampilan yang diperlukan untuk menjalankan fungsinya dalam organisasi. Modal manusia ditetapkan memiliki empat faktor kombinasi dalam tingkatan individu, yaitu warisan genetik, pendidikan, pengalaman, dan sikap terhadap kehidupan dan bisnis (Bontis, 1998).

\section{Pengaruh Modal Pelanggan $\left(\mathrm{X}_{2}\right)$ terhadap Kinerja Bisnis ( $\left.\mathrm{Y}\right)$}

Variabel modal pelanggan mempunyai pengaruh positif dan signifikan terhadap kinerja bisnis. Temuan ini sesuai dengan prediksi hipotesis $\left(\mathrm{H}_{2}\right)$ yang memprediksi bahwa modal pelanggan secara positif dan signifikan berpengaruh terhadap kinerja bisnis lembaga keuangan mikro usaha ekonomi kelurahan simpan pinjam. Makna dari temuan ini menunjukkan bahwa secara empiris modal pelanggan selalu atau merupakan faktor penentu dalam meningkatkan kinerja bisnis. Temuan ini juga mengindikasikan bahwa kinerja bisnis lembaga keuangan mikro usaha ekonomi kelurahan simpan pinjam dapat ditentukan oleh variabel modal pelanggan.

Hasil penelitian ini sesuai dengan hasil penelitian dari Wang dan Chang (2005) yang menunjukkan hubungan antar komponen intellectual capital, yaitu human capital, innovation capital, process capital dan customer capital, dan bagaimana hubungan antar komponen tersebut dapat mempengaruhi kinerja bisnis.

Modal pelanggan merupakan komponen modal intelektual yang memberikan nilai secara nyata (Bontis: 1998). Elemen ini merupakan hubungan yang harmonis yang dimiliki oleh perusahaan dengan para mitranya, baik yang berasal dari para pemasok yang andal dan berkualitas, berasal dari pelanggan yang loyal dan merasa puas akan pelayanan UEK SP yang bersangkutan, berasal dari hubungan UEK SP dengan pemerintah maupun dengan masyarakat sekitar.

\section{Pengaruh Modal Struktural $\left(\mathrm{X}_{3}\right)$ terhadap Kinerja Bisnis $(\mathbf{Y})$}

Variabel modal struktural mempunyai pengaruh yang signifikan terhadap kinerja bisnis. Temuan ini sesuai dengan prediksi hipotesis $\left(\mathrm{H}_{3}\right)$ yang memprediksi bahwa terdapat pengaruh modal struktural terhadap kinerja bisnis lembaga keuangan mikro usaha ekonomi kelurahan simpan pinjam (UEK SP). Makna dari temuan ini menunjukkan bahwa secara 
INOBIS: Jurnal Inovasi Bisnis dan Manajemen Indonesia

Volume 1, Nomor 4, September 2018

Bambang Supeno

empiris modal struktural selalu atau merupakan faktor penentu dalam meningkatkan kinerja bisnis. Temuan ini juga mengindikasikan bahwa kinerja bisnis lembaga keuangan UEK SP dapat ditentukan oleh variabel modal struktural.

Hasil penelitian ini sesuai dengan hasil penelitian dari Jardon dan Martos (2009) yang menunjukkan human capital, relational capital dan structural capital berpengaruh terhadap kinerja perusahaan, tetapi hanya structural capital yang berpengaruh langsung terhadap kinerja bisnis.

Perngaruh modal struktural yang besar terhadap kinerja bisnis UEK SP di Kota Pekanbaru, Karena ikut campur tangan pemerintah terhadap UEK SP yang mengakibatkan kinerja UEK SP tidak alami, hal ini terjadi karena pengelola UEK SP belum mampu mengelola UEK SP secara professional dan mandiri, yang pada dasarnya ini merupakan kelemahan system manajemen (pengelolaan).

Modal struktural merupakan kemampuan organisasi atau lembaga bisnis dalam memenuhi proses rutinitas perusahaan dan strukturnya yang mendukung usaha karyawan untuk menghasilkan kinerja intelektual yang optimal serta kinerja bisnis secara keseluruhan. Modal struktural juga berhubungan dengan mekanisme/sistem dan struktur perusahaan. Perusahaan dengan modal struktural yang kuat akan menciptakan kondisi yang diinginkan untuk memanfaatkan modal manusia dan memungkinkan modal manusia untuk merealisasikan seluruh potensi dan kemudian membangkitkan modal inovasi dan modal hubungan. Secara rinci, modal struktural dapat diklasifikasikan menjadi budaya perusahaan, struktur organisasi, pembelajaran organisasi, proses operasional, dan sistem informasi.

\section{Pengaruh Modal Manusia $\left(\mathbf{X}_{1}\right)$, Modal Pelanggan $\left(\mathbf{X}_{2}\right)$ dan Modal Struktural $\left(\mathbf{X}_{3}\right)$ terhadap Kinerja Bisnis (Y)}

Modal manusia, modal pelangan dan modal struktural secara simultan mempunyai pengaruh terhadap kinerja bisnis. Temuan ini sesuai dengan prediksi hipotesis $\left(\mathrm{H}_{3}\right)$ yang memprediksi bahwa terdapat pengaruh modal manusia dan modal pelanggan terhadap kinerja bisnis lembaga keuangan mikro usaha ekonomi desa simpan pinjam.

Hasil penelitian ini sesuai dengan hasil penelitian dari Bollen et al (2005) yang menunjukkan Lebih lanjut ditemukan bahwa modal manusia, modal struktural dan modal pelanggan memiliki pengaruh terhadap intellectual property yang secara tidak langsung mempengaruhi kinerja bisnis.

Human capital lembaga bisnis memiliki potensi untuk membangun orientasi pasar bagi konsumen. Semakin baik kompetensi pegawai, maka akan semakin baik pegawai memahami kebutuhan konsumen dan akan semakin mampu pula mengembangkan customer capital untuk menahan loyalitas konsumen. Perusahaan yang berinvestasi besar untuk menjadi fokus pada konsumen dan menjadi penentu pasar secara mutlak akan dapat meningkatkan atau memperbaiki business performance-nya. Konsumen merupakan kunci survive atau tidaknya suatu perusahaan. Jika konsumen loyal terhadap perusahaan, maka business performance akan dapat terjaga.

Sumber daya manusia yang diberdayagunakan secara efisien merupakan salah satu faktor yang mampu meningkatkan produktivitas. Namun, di lain pihak sumber daya manusia juga dapat menjadi pemicu terjadinya pemborosan dan inefisiensi dalam berbagai bentuk. Hal ini terjadi bila manajemen organisasi tidak mampu merumuskan kebijaksanaan pengelolaan sumber daya manusia dalam organisasi dan menjalankan praktek-praktek manajemen sumber daya manusia yang tepat. 
INOBIS: Jurnal Inovasi Bisnis dan Manajemen Indonesia

Volume 1, Nomor 4, September 2018

\section{Bambang Supeno}

Modal struktural merupakan hal yang sangat penting bagi sebuah organisasi guna menciptakan nilai tambah untuk produk yang dihasilkan dan untuk mendapatkan keuntungan kompetitif. jika sebuah organisasi memiliki modal struktural yang sangat buruk, maka akan sangat sulit untuk meraih manfaat penuh dari IC secara keseluruhan. Modal struktural yang kuat dapat membuat sebuah organisasi menarik manfaat secara maksimum dari IC yang dimiliknya. Dapat disimpulkan bahwa modal struktural dari sebuah organisasi terdiri dari infrastruktur, sistem dan kebijakan, serta prosedur sebuah organisasi yang mempunyai pengaruh terhadap kinerja bisnis.

\section{Kesimpulan}

Berdsarkan hasil analisis lapangan, wawancara, pengelolaan data maka dapat disimpulkan sebagai berikut :

1. modal manusia berpengaruh terhadap kinerja bisnis lembaga keuangan mikro usaha ekonomi desa simpan pinjam. Temuan ini menunjukkan bahwa secara empiris kinerja bisnis UEK SP Kota Pekanbaru.

2. Modal pelanggan berpengaruh terhadap kinerja bisnis lembaga keuangan mikro usaha ekonomi desa simpan pinjam. Temuan ini sesuai dengan prediksi hipotesis yang memprediksi bahwa terdapat pengaruh modal pelanggan terhadap kinerja bisnis lembaga keuangan mikro usaha ekonomi desa simpan pinjam. Makna dari temuan ini menunjukkan bahwa secara empiris modal pelanggan ekonomi selalu atau merupakan faktor penentu kinerja bisnis lembaga keuangan mikro usaha ekonomi desa simpan pinjam.

3. Modal struktural berpengaruh terhadap kinerja bisnis lembaga keuangan mikro usaha ekonomi desa simpan pinjam. Temuan ini sesuai dengan prediksi hipotesis yang memprediksi bahwa terdapat pengaruh modal struktural terhadap kinerja bisnis lembaga keuangan mikro usaha ekonomi desa simpan pinjam. Makna dari temuan ini menunjukkan bahwa secara empiris modal struktural ekonomi selalu atau merupakan faktor penentu kinerja bisnis lembaga keuangan mikro usaha ekonomi desa simpan pinjam. Temuan ini juga mengindikasikan bahwa kinerja bisnis lembaga keuangan mikro usaha ekonomi desa simpan pinjam dapat ditentukan oleh variabel modal struktural.

4. Modal manusia, modal pelanggan dan modal struktural berpengaruh terhadap kinerja bisnis UEK SP Kota Pekanbaru. Temuan ini sesuai dengan prediksi hipotesis yang memprediksi bahwa terdapat pengaruh modal manusia, modal pelanggan dan modal struktural terhadap kinerja bisnis UEK SP.

\section{Daftar Pustaka}

Astuti, Partiwi Dwi dan Arifin Sabeni, 2005, Hubungan Intellectual Capital dan Business Performance dengan Diamond Spesification, Sebuah Perspektif Akuntansi, Makalah disaijkan dalam SNA, Solo, 15-16 September.

Bambang Supeno dan Mujiono, 2015, Pengaruh Modal Manusia dan Modal Pelanggan Terhadap Kinerja Bisnis Lembaga Keuangan Mikro (Studi Pada Usaha Ekonomi Desa Simpan Pinjam di Provinsi Riau), Prosiding Seminar Nasional Industri dan Teknologi Politeknik Negeri Bengkalis, ISSN: 2303-2790, hal. 177-186.

Bontis, Nick and Fitz-enz, Jac., 2002, Intellectual Capital ROI, a Causal Map of Human Capital Antecedents and Consequents, Journal of Intellectual Capital, Vol. 3(3): 223247. 
INOBIS: Jurnal Inovasi Bisnis dan Manajemen Indonesia

Volume 1, Nomor 4, September 2018

Bambang Supeno

Bontis N. 1998. Intellectual Capital : an explanatory study that develops measures and models, Managements Decision, Vol. 36 (2): 63-76.

Brennan, N., 2001, Reporting Intellectual Capital in Annual Reports: Evidence from Ireland. Accounting, Auditing and Accountability Journal, (Online) 14(4): 423-436, (http://dx.doi.org/10.1108/09513570110403443, diakses 10 Juli 2012).

Brinker, Barry, 2000, Intellectual Capital: Tomorrows Asset, Today's Challenge. (Online), (http://www.cpavision.org/vision/wpaper05b.cfm, diakses 16 Juli 2012).

Dwipayana, Ari AAGN, 2007, Membangun Good Governance di Desa. Yogyakarta: Institute For Research And Empowerment (Ire Press).

Ghozali, Imam, 2011, Aplikai Analisis Multivarite dengan SPSS, Cetakan Keempat. Semarang: Badan Penerbit Universitas Diponegoro.

Gujarati, D., 2011, Basic Econometrics. Edisi Terjemahan, Cetakan Ketujuh. Mc-Grawhill. New York.

Ikbal Wahid dan Muhammad Ridwan. 2015, Evaluasi Pelaksanaan Program Pemberdayaan Desa (PPD) Melalui Usaha Ekonomi Kelurahan Simpan Pinjam (UEK-SP) Di Kelurahan Bukit Kayu Kapur Kota Dumai Tahun 2012, Jurnal Online Mahasiswa (JOM) Bidang Ilmu Sosial dan Ilmu Politik, Vol. 2, No. 2, 01 Januari 2015, hal.1-15.

John W. Creswell, 2015, Penelitian Kualitatif dan Desain Riset, Pustaka Pelajar, Yogyakata.

Michael A, Hitt., Ireland, R. Duane Hoskisson, Rrobert E., 2002, Manajemen Strategis: Daya Saing \& Globalisasi. Jakarta: Salemba Empat.

Purnomosidhi, Bambang, 2006, Praktik Pengungkapan Modal Intelektual pada Perusahaan Publik di BEJ, Jurnal Riset Akuntansi Indonesia, Vol.9 (1): 1-20

Riau Pos. 9 April, 2010, Program UED-SP Cikal Bakal BUMDes di Riau, hal 3.

Rencana Pembangunan Jangka Menengah Nasional 2014-2019. 2014. Jakarta: BAPPENAS

Salam, Dharma Setyawan, 2008, Manajemen Pemerintahan Indonesia. Jakarta: Djambatan

Sawarjuwono, T., dan A. P. Kadir, 2003, Intellectual Capital: Perlakuan, Pengukuran dan Pelaporan, Jurnal Akuntansi dan Keuangan, Vol. 5 (1): 35-57.

Surat Keputusan Gubernur Riau Nomor Kpts.132/III/2005 tanggal 31 Maret 2005 tentang Pedoman Umum dan Petunjuk Teknis Penyelenggaraan Program Pemberdayaan Desa (PPD). 2005. Pekanbaru: Pemerintah Provinsi Riau.

Stockely, 2003, Human Capital Measurement How to Do You Measure Up, Accenture Human Performance Insight.

Sugiyono, 2015, Metode Penelitian Manajemen, Alfa Beta, Bandung

Solimun. 2009. Metode Kulaitatif untuk Manajemen. Program Studi S3 Manajemen Universitas Brawijaya, Malang.

Suliyanto, 2011, Ekonometrika Terapan: Teori dan Aplikasi dengan SPSS, Yogyakarta: Andi Yogyakarta.

Ulum, Ihyaul, 2009, Model Inter-relasi Antar Komponen Modal Intelektual (Human Capital, Structural Capital, Customer Capital) dan Kinerja Perusahaan. Jurnal Humanity, Vol.4 (2): 134-140.

Wang, W-Y. and Chang, C., 2005, Intellectual Capital and Performance in Causal Model: Evidence From The Information Technology Industry in Taiwan, Journal of Intellectual Capital, Vol. 6(2): 222-236.

Wiloejo Wirjo, 2005, Pemberdayaan Lembaga Keuangan Mikro Sebagai Salah Satu Pilar Sistem Keuangan Nasional: Upaya Konkrit Memutus Mata Rantai Kemiskinan, Jakarta: Kajian Ekonomi dan Keuangan. (online), (www.fiskal.depkeu.go.id, diakses 18 Juni 2012). 